\title{
Response to insulin of the intact stomach in patients with duodenal ulcer
}

\author{
G. Gillespie, I. E. Gillespie, AND A. W. KAY \\ From the University Department of Surgery, Western Infirmary, Glasgow
}

SUMMARY Insulin tests were performed on 47 duodenal ulcer patients with intact stomachs. Only 20 had a positive response to the test judged positive by the criteria of Hollander in the first 45 minutes after the insulin. Twenty became positive between 45 and 60 minutes, and in five the response was not noted until the second hour. Surprisingly, two patients had apparently negative responses to the insulin. While caution is necessary in comparing responses of the intact stomach to those after vagotomy operations, the occurrence of the 'late positive' and negative patterns of response to insulin in the intact stomach may give rise to reservations about the interpretation of these types of response after vagotomy.

Measurement of the gastric acid secretory response to insulin is the most widely accepted method in use to determine the completeness of surgical vagotomy.

Among the many criteria which have been proposed to indicate a positive response and therefore incomplete vagotomy, the most universally adopted criteria are those proposed by Hollander (1946). Using these criteria there have been wide variations in the incidence of incomplete vagotomy reported from different surgical series, $14 \%$ by Woodward, Harper, Tovee, and Dragdstedt (1949), $43 \%$ by Weinstein, Hollander, Lauber, and Colp (1950), $30 \%$ by Davies (1956), $12 \%$ by Lythgoe (1961), and $27 \%$ by Ross (1964).

By contrast the reported incidence of recurrent ulcer after vagotomy and drainage for duodenal ulcer is relatively low, being reported as $3.6 \%$ by Burge (1960), $1 \%$ by Holt and Lythgoe (1961), and $5.7 \%$ by Feggeter and Pringle (1963).

The apparent discrepancy between the incidence of incomplete vagotomy, as shown by the insulin test, and the incidence of recurrent ulcer has led to various attempts to see whether other interpretations of the response to insulin might reveal closer correlation between the response and risk of recurrent ulcer (Ross and Kay, 1964; Bank, Marks, and Louw, 1967).

Little is known of the pattern of gastric acid secretory response to insulin in duodenal ulcer subjects before surgery, and it is not known whether the preoperative response may influence the postoperative pattern. In addition, although hypoglycaemia is known to initiate the vagal impulses, it is not known which aspect of the hypoglycaemia, eg absolute level of blood sugar concentration, proportional reduction, or rate of reduction, is the most critical factor.

In this paper the results of a study of insulin responses in a consecutive series of 47 patients awaiting surgery for duodenal ulcer are presented. In 46 the presence of duodenal ulcer was subsequently confirmed at laparotomy. The remaining patient, who had a radiologically demonstrated duodenal ulcer, refused surgery. In 18 patients the pattern of hypoglycaemia in response to insulin was further analysed in detail using various parameters of both the blood sugar changes and the acid response.

\section{METHODS}

A maximal pentagastrin test and an insulin test were performed preoperatively in 46 patients. The remaining patient had a preoperative insulin test only.

All secretory measurements were made after a 12-hour fast. After removal of the fasting juice, the gastric secretion was aspirated continuously by an electric suction apparatus, and every 15 minutes measurements were made of volume $(\mathrm{ml})$, acid concentration (m-equiv/l), and acid output (m-equiv).

MAXIMAL PENTAGASTRIN TEST After two basal 15-minute collections, pentagastrin, $6 \mu \mathrm{g} / \mathrm{kg}$, was injected intramuscularly. Four further 15-minute aspirates were collected and measured for volume, acid concentration, and acid output.

INSULIN TEST Two 15-minute basal aspirates were collected, as in the maximal pentagastrin test, and thereafter 
insulin (20 units) was injected intravenously and a further eight 15-minute aspirates were collected. A positive response was indicated by an increase in acid concentration of $20 \mathrm{~m}$-equiv/l over preinsulin levels. An increase of $10 \mathrm{~m}$-equiv/l was accepted as positive if there was no acid before the insulin injection. Blood sugar concentration was measured by AutoAnalyzer in the fasting state and at 30 minutes and 45 minutes after insulin.

MORE DETAILED HYPOGLYCAEMIA PATTERN STUDY In 18 patients a more detailed study was made with more frequent measurements of both blood sugar concentration and gastric acid response.

Blood sugar concentration was measured in the fasting state and serially at three-minute intervals throughout the test. Antecubital venous blood samples were obtained from an indwelling venous catheter (Intracath). In addition three patients provided arterial blood samples from a Riley cannula inserted into the brachial artery; thus in these patients synchronous arterial and venous sampling was possible, sugar concentrations being estimated by the Folin-Wu technique.

Volume, acid concentration, and acid output of gastric juice were measured every five minutes and, for ready comparison with the results in the other patients, the 15-minute volumes and outputs were derived from simple addition of three consecutive five minute values. Mean 15-minute acid concentration was determined by dividing the sum of the three consecutive acid outputs by the sum of the three corresponding volumes.

\section{RESULTS}

THE INSULIN RESPONSE Of the 47 preoperative insulin tests, 45 showed responses which would satisfy Hollander's criteria for a positive response; two were apparently negative, and if they had been postoperative tests would have been interpreted as indicating complete vagotomy. In one, basal acid concentration was high, and the postinsulin concentrations only narrowly failed to satisfy Hollander's criteria. However, no unusual feature of basal secretion was noted in the other negative test.

The insulin-positive responses were analysed with respect to the time after the insulin injection at which they became positive (Fig. 1). The majority fulfilled Hollander's positive criteria in the first hour after insulin. However, almost equal numbers satisfied the criteria in the period 45 to 60 minutes after insulin and in the period before 45 minutes.

In five patients the insulin response became positive in the second hour after insulin, in three at 75 minutes, in one at 90 minutes, and in one at 105 minutes.

RELATIONSHIP OF TIMING OF THE INSULIN RESPONSE TO 'MAXIMAL' RESPONSE TO PENTAGASTRIN For each patient the time of onset of the positive insulin response was compared with the acid secretory

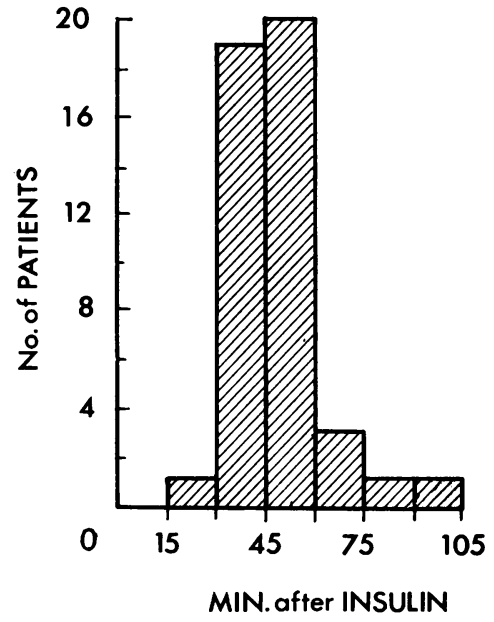

FIG. 1. Timing of positive insulin response in 45 patients. Timing refers to the first 15-minute period during which the criteria of Hollander were satisfied.

response to a maximal dose of pentagastrin (Fig. 2). There was no significant correlation between these two measurements.

RELATIONSHIP OF THE PEAK ACID RESPONSE TO INSULIN TO MAXIMAL RESPONSE TO PENTAGASTRIN Figure 3 compares the peak acid response to insulin with the peak response to a maximal pentagastrin dose. While the correlation between these two acid measurements

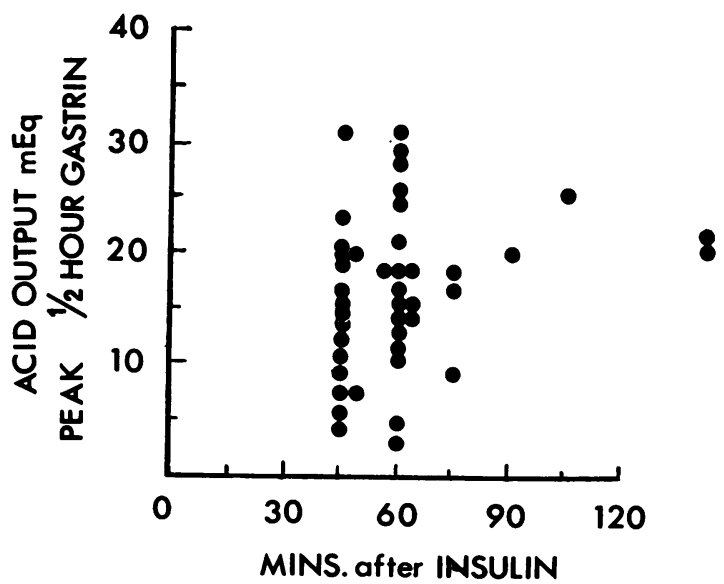

FIG. 2. Timing of insulin response in relation to maximal pentagastrin output in 46 patients. The two patients indicated as off the scale to the right were those with apparently negative responses to insulin. No statistically significant correlation existed for the two different measurements. 


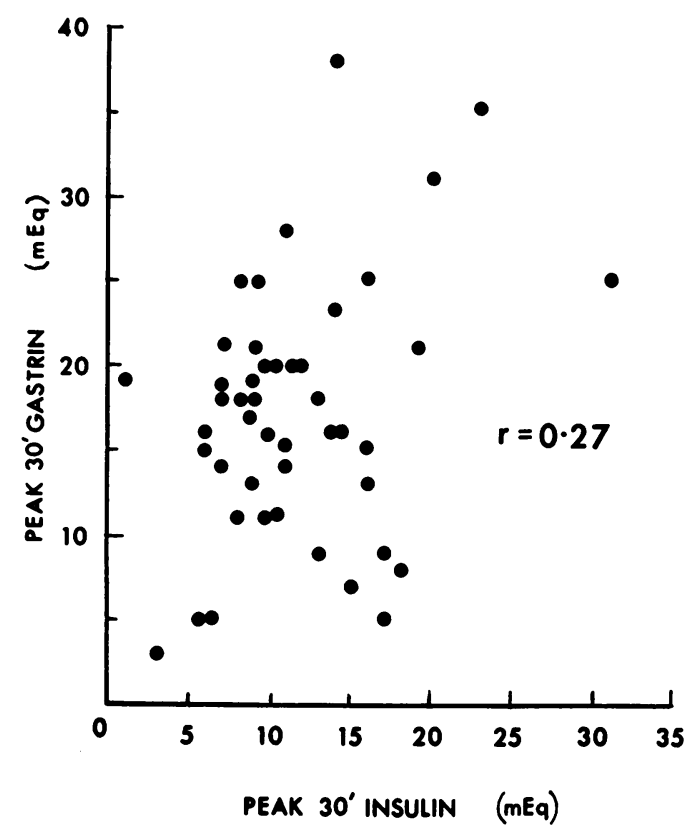

FIG. 3. Peak pentagastrin 30-min output in relation to peak insulin 30-min output in 46 patients. This low correlation coefficient is only of borderline statistical significance $(\mathrm{P}>0.05$.)

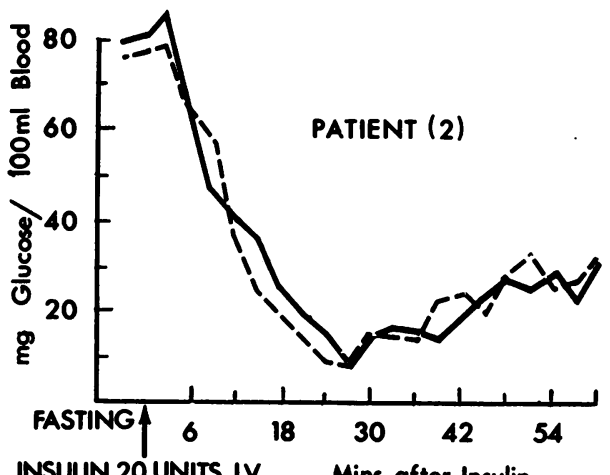

INSULIN 20 UNITS I.V. Mins. after Insulin is of borderline significance, the peak response to this dose of insulin was within $15 \%$ of the maximal to pentagastrin in only 12 of the 46 patients.

RELATIONSHIP OF HYPOGLYCAEMIA TO GASTRIC ACID SECRETION These results refer to the 18 patients in whom more frequent samples of blood and gastric juice were taken. Since it has been shown that, at the higher levels of blood sugar in diabetes mellitus, arterial or capillary blood sampling gives a less variable and more reliable estimate of blood sugar than does venous sampling (Butterfield, 1967), comparison was first made of venous and arterial sampling in the low blood sugar range found after insulin administration, in three patients. No significant difference was obtained (Fig. 4), and it was therefore concluded that venous blood was satisfactory for measurement of the hypoglycaemia pattern.

Correlations were sought between, on the one hand various measurements relating to different features of the hypoglycaemic pattern, and on the other hand various measurements of acid response to the insulin. In addition the possibility of correlation between these same measurements and maximal response to pentagastrin was sought. In short, correlation coefficients were determined for each possible pair of the measurements listed in Table I. Highly significant correlations $(P<0.01)$ occurred only for pairs of

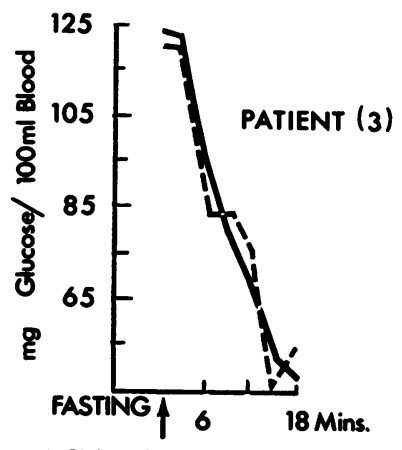

FIG. 4. Arterial and venous blood sugar curves after insulin administration. The curves are almost identical.

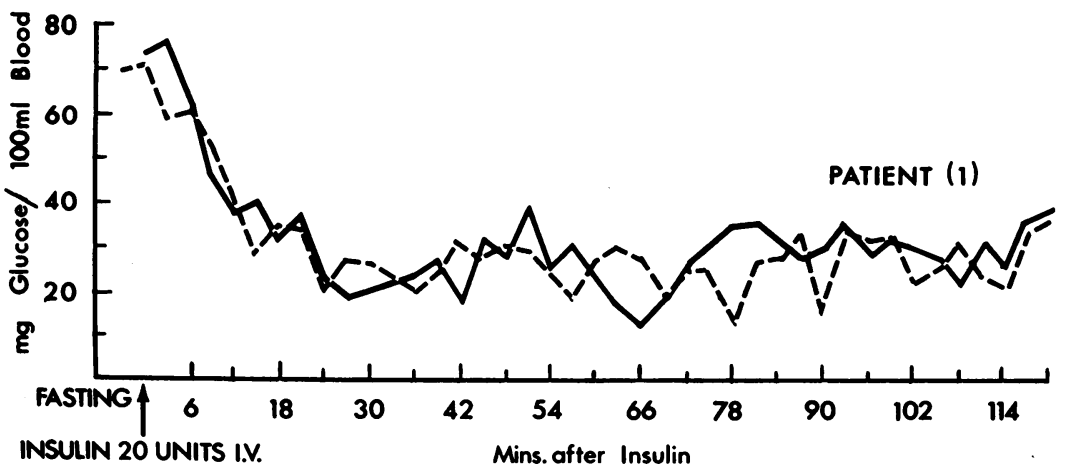


Response to insulin of the intact stomach in patients with duodenal ulcer

TABLE la

MEASUREMENTS OF HYPOGLYCAEMIC PATTERN AND ACID SECRETORY RESPONSE

\begin{tabular}{|c|c|c|c|c|c|c|c|c|c|c|c|c|c|c|c|c|c|c|}
\hline & 1 & 2 & 3 & 4 & 5 & 6 & 7 & 8 & 9 & 10 & 11 & 12 & 13 & 14 & 15 & 16 & 17 & 18 \\
\hline Case & $\begin{array}{l}\text { Time } \\
\text { after } \\
\text { Insulin } \\
\text { to } \\
\text { Onset } \\
\text { of } \\
\text { Acid } \\
\text { Stimu- } \\
\text { lation } 1 \\
\text { (min) }\end{array}$ & $\begin{array}{l}\text { Time } \\
\text { after } \\
\text { Insulin } \\
\text { to } \\
\text { Test } \\
\text { Posi- } \\
\text { tive } \\
\text { (min) }\end{array}$ & $\begin{array}{l}\text { Time } \\
\text { after } \\
\text { Onset } \\
\text { of } \\
\text { Acid } \\
\text { Stimu- } \\
\text { lation } \\
\text { to } \\
\text { Test } \\
\text { Posi- } \\
\text { tive } \\
\text { (min) }\end{array}$ & $\begin{array}{l}\text { Time } \\
\text { from } \\
\text { Blood } \\
\text { Sugar } \\
(40 \mathrm{mg} \\
\%) \\
\text { to } \\
\text { Onset } \\
\text { of } \\
\text { Acid } \\
\text { Stimu- } \\
\text { lation } \\
\text { (min) }\end{array}$ & $\begin{array}{l}\text { Time } \\
\text { from } \\
\text { Blood } \\
\text { Sugar } \\
(40 \mathrm{mg} \\
\%) \\
\text { to } \\
\text { Test } \\
\text { Posi- } \\
\text { tive } \\
\text { (min) }\end{array}$ & $\begin{array}{l}\text { Time } \\
\text { from } \\
\text { Blood } \\
\text { Sugar } \\
(50 \mathrm{mg} \\
\%) \\
\text { to } \\
\text { Onset } \\
\text { of } \\
\text { Acid } \\
\text { Stimu- } \\
\text { lation } \\
\text { (min) }\end{array}$ & $\begin{array}{l}\text { Time } \\
\text { from } \\
\text { Blood } \\
\text { Sugar } \\
\text { (50 mg } \\
\%) \\
\text { to } \\
\text { Test } \\
\text { Posi- } \\
\text { tive } \\
\text { (min) }\end{array}$ & $\begin{array}{l}\text { Blood } \\
\text { Sugar } \\
\text { at } \\
\text { Onset } \\
\text { of } \\
\text { Acid } \\
\text { Stimu- } \\
\text { lation } \\
\text { (mg \%) }\end{array}$ & $\begin{array}{l}\text { Lowest } \\
\text { Blood } \\
\text { Sugar } \\
\text { before } \\
\text { Acid } \\
\text { Stimu- } \\
\text { lation } \\
\text { (mg \%) }\end{array}$ & $\begin{array}{l}\text { Lowest } \\
\text { Blood } \\
\text { Sugar } \\
\text { During } \\
\text { Test } \\
\text { (mg \%) }\end{array}$ & $\begin{array}{l}\text { Blood } \\
\text { Sugar } \\
\text { at } \\
\text { Onset } \\
\text { of } \\
\text { Acid } \\
\text { Stimu- } \\
\text { lation } \\
\text { (\% of } \\
\text { Fasting } \\
\text { Sugar) }\end{array}$ & $\begin{array}{l}\text { Blood } \\
\text { Sugar } \\
\text { at } \\
\text { Test } \\
\text { Posi- } \\
\text { tive } \\
\text { (\% of } \\
\text { Fasting } \\
\text { Sugar) }\end{array}$ & $\begin{array}{l}\text { Weight } \\
(\boldsymbol{k g})\end{array}$ & $\begin{array}{l}\text { Rate of } \\
\text { Fall of } \\
\text { Blood } \\
\text { Sugar } \\
\text { before } \\
\text { Onset } \\
\text { of } \\
\text { Acid } \\
\text { Stimu- } \\
\text { lation } \\
\text { (mg/min }\end{array}$ & $\begin{array}{l}\text { Basal } \\
\text { Half } \\
\text { Hour } \\
\text { Acid } \\
\text { Output } \\
\text { ( } m- \\
\text { equiv) } \\
\\
\text { in) }\end{array}$ & $\begin{array}{l}\text { Two- } \\
\text { hour } \\
\text { Insulin } \\
\text { Acid } \\
\text { (Output } \\
\text { (m- } \\
\text { equiv) }\end{array}$ & $\begin{array}{l}\text { Peak } \\
\text { Half- } \\
\text { hour } \\
\text { Gastrin } \\
\text { t Output } \\
\text { (m- } \\
\text { equiv) }\end{array}$ & $\begin{array}{l}\text { Rate of } \\
\text { Rise of } \\
\text { Acid } \\
\text { Concen- } \\
\text { tration } \\
\text { after } \\
\text { Insulin } \\
\text { (m- } \\
\text { equiv| } \\
\text { min) }\end{array}$ \\
\hline $\begin{array}{r}1 \\
2 \\
3 \\
4 \\
5 \\
6 \\
7 \\
8 \\
9 \\
10 \\
11 \\
12 \\
13 \\
14 \\
15 \\
16 \\
17 \\
18\end{array}$ & $\begin{array}{l}45 \\
25 \\
30 \\
30 \\
40 \\
25 \\
50 \\
25 \\
30 \\
20 \\
20 \\
35 \\
30 \\
25 \\
30 \\
35 \\
30 \\
30\end{array}$ & $\begin{array}{l}58 \\
40 \\
39 \\
44 \\
50 \\
37 \\
64 \\
40 \\
36 \\
40 \\
24 \\
38 \\
39 \\
43 \\
37 \\
45 \\
39 \\
38\end{array}$ & $\begin{array}{r}13 \\
15 \\
9 \\
14 \\
10 \\
12 \\
14 \\
15 \\
6 \\
20 \\
4 \\
3 \\
9 \\
18 \\
7 \\
10 \\
9 \\
8\end{array}$ & $\begin{array}{r}-9 \\
9 \\
9 \\
9 \\
5 \\
25 \\
13 \\
3 \\
3 \\
2 \\
10 \\
4 \\
4 \\
12 \\
13 \\
13\end{array}$ & $\begin{array}{r}- \\
24 \\
18 \\
23 \\
19 \\
17 \\
39 \\
28 \\
9 \\
17 \\
6 \\
13 \\
13 \\
22 \\
0 \\
22 \\
22 \\
21\end{array}$ & $\begin{array}{r}23 \\
11 \\
12 \\
12 \\
17 \\
9 \\
28 \\
14 \\
5 \\
0 \\
6 \\
14 \\
7 \\
8 \\
0 \\
15 \\
14 \\
14\end{array}$ & $\begin{array}{r}36 \\
26 \\
21 \\
26 \\
27 \\
21 \\
42 \\
29 \\
11 \\
20 \\
10 \\
27 \\
16 \\
26 \\
7 \\
25 \\
23 \\
22\end{array}$ & $\begin{array}{l}49 \cdot 5 \\
34 \cdot 0 \\
25 \cdot 5 \\
28 \cdot 0 \\
43 \cdot 0 \\
35 \cdot 0 \\
45 \cdot 0 \\
26 \cdot 0 \\
38 \cdot 0 \\
50 \cdot 0 \\
27 \cdot 5 \\
27 \cdot 5 \\
32.0 \\
28 \cdot 0 \\
50 \cdot 0 \\
35.0 \\
28 \cdot 5 \\
25.0\end{array}$ & $\begin{array}{l}44 \cdot 5 \\
29 \cdot 5 \\
25 \cdot 5 \\
28 \cdot 0 \\
38 \cdot 0 \\
35 \cdot 0 \\
35 \cdot 0 \\
26 \cdot 0 \\
38 \cdot 0 \\
50 \cdot 0 \\
27 \cdot 5 \\
27 \cdot 5 \\
31 \cdot 5 \\
26 \cdot 5 \\
50 \cdot 0 \\
32.0 \\
28 \cdot 5 \\
22.5\end{array}$ & $\begin{array}{l}44 \cdot 5 \\
28 \cdot 5 \\
24 \cdot 5 \\
26 \cdot 5 \\
32 \cdot 5 \\
33 \cdot 5 \\
35 \cdot 0 \\
15 \cdot 5 \\
37 \cdot 0 \\
36 \cdot 0 \\
19 \cdot 2 \\
25 \cdot 5 \\
30 \cdot 5 \\
18 \cdot 0 \\
41 \cdot 5 \\
32 \cdot 0 \\
28.5 \\
22 \cdot 5\end{array}$ & $\begin{array}{l}46 \cdot 0 \\
34 \cdot 3 \\
24 \cdot 5 \\
28 \cdot 0 \\
51 \cdot 2 \\
40 \cdot 0 \\
40 \cdot 9 \\
33 \cdot 5 \\
32 \cdot 8 \\
49 \cdot 8 \\
26 \cdot 7 \\
25 \cdot 3 \\
29 \cdot 2 \\
28 \cdot 9 \\
52 \cdot 6 \\
34 \cdot 1 \\
27 \cdot 9 \\
26 \cdot 3\end{array}$ & $\begin{array}{l}47 \cdot 4 \\
43 \cdot 4 \\
23 \cdot 6 \\
47 \cdot 5 \\
45 \cdot 8 \\
42 \cdot 3 \\
37 \cdot 7 \\
48 \cdot 4 \\
34 \cdot 5 \\
51 \cdot 7 \\
27 \cdot 7 \\
24 \cdot 0 \\
28 \cdot 3 \\
40 \cdot 7 \\
54 \cdot 2 \\
36 \cdot 1 \\
35 \cdot 3 \\
53 \cdot 6\end{array}$ & $\begin{array}{l}71 \cdot 55 \\
66 \cdot 13 \\
56 \cdot 7 \\
54 \cdot 0 \\
55 \cdot 8 \\
72 \cdot 5 \\
73 \cdot 8 \\
52 \cdot 2 \\
69 \cdot 3 \\
61 \cdot 2 \\
63 \cdot 0 \\
78 \cdot 8 \\
65 \cdot 7 \\
63 \cdot 0 \\
49 \cdot 1 \\
69 \cdot 3 \\
68 \cdot 4 \\
55 \cdot 8\end{array}$ & $\begin{array}{l}2 \cdot 35 \\
3 \cdot 31 \\
2 \cdot 62 \\
2 \cdot 4 \\
1 \cdot 39 \\
2 \cdot 1 \\
2 \cdot 8 \\
2 \cdot 08 \\
2 \cdot 6 \\
2 \cdot 53 \\
3 \cdot 78 \\
2 \cdot 31 \\
2 \cdot 6 \\
2 \cdot 76 \\
1 \cdot 5 \\
2 \cdot 0 \\
2 \cdot 45 \\
3 \cdot 02\end{array}$ & $\begin{array}{l}3 \cdot 6 \\
0 \cdot 7 \\
4 \cdot 7 \\
9 \cdot 1 \\
1 \cdot 5 \\
9 \cdot 8 \\
3 \cdot 3 \\
0 \cdot 8 \\
0 \cdot 5 \\
2 \cdot 4 \\
1 \cdot 4 \\
1 \cdot 9 \\
7 \cdot 3 \\
4 \cdot 0 \\
0.9 \\
6 \cdot 6 \\
2.7 \\
3.7\end{array}$ & $\begin{array}{c}23 \cdot 8 \\
15 \cdot 9 \\
29 \cdot 3 \\
27 \cdot 7 \\
15 \cdot 6 \\
55 \cdot 5 \\
19 \cdot 8 \\
15 \cdot 8 \\
37 \cdot 4 \\
40 \cdot 0 \\
68 \cdot 5 \\
26 \cdot 6 \\
41 \cdot 2 \\
22 \cdot 0 \\
22 \cdot 6 \\
61 \cdot 7 \\
42 \cdot 4 \\
26 \cdot 8\end{array}$ & $\begin{array}{c}18 \cdot 0 \\
15 \cdot 6 \\
20 \cdot 3 \\
28 \cdot 4 \\
10 \cdot 6 \\
30 \cdot 7 \\
16 \cdot 5 \\
4 \cdot 6 \\
12 \cdot 1 \\
16 \cdot 2 \\
34 \cdot 8 \\
16 \cdot 4 \\
7 \cdot 4 \\
18 \cdot 1 \\
19 \cdot 6 \\
31 \cdot 0 \\
21 \cdot 4\end{array}$ & $\begin{array}{l}2 \cdot 2 \\
2 \cdot 1 \\
4 \cdot 4 \\
3 \cdot 6 \\
3 \cdot 2 \\
3 \cdot 3 \\
3 \cdot 3 \\
1 \cdot 7 \\
4 \cdot 0 \\
1 \cdot 2 \\
2 \cdot 2 \\
3 \cdot 1 \\
4 \cdot 4 \\
2 \cdot 1 \\
3 \cdot 9 \\
3 \cdot 7 \\
5 \cdot 9 \\
1 \cdot 8\end{array}$ \\
\hline
\end{tabular}

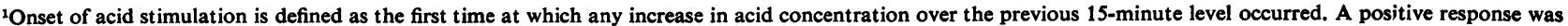
defined according to Hollander's criteria.

TABLE Ib

CORRELATION BETWEEN PAIRS OF MEASUREMENTS IN TABLE Ia WHICH REACHED BORDERLINE STATISTICAL SIGNIFICANCE $(0.01<\mathrm{P}<0.05)$

Blood sugar levels at onset of acid stimulation (no. 11)

Lowest blood sugar recorded (no. 10)

Rate of fall in blood sugar (no. 14)

Total acid response to insulin over two hours (no. 16)

\author{
Time after insulin to positive response (no. 2) \\ Time after insulin to onset of acid stimulation (no. 1) \\ Proportional fall in blood sugar (no. 11) \\ A Time after insulin to positive response (no. 2) \\ B Time from blood sugar 40 or $50 \mathrm{mg}$ per $100 \mathrm{ml}$ to positive response \\ (no. 5) \\ C Peak acid response to maximal dose of pentagastrin
}

measurements dealing with the same basic observations, eg, different time measurements (nos. 1 to 7 in Table Ia) and different expressions of blood sugar concentrations (nos. 8 to 11 in Table Ia). Those correlations which reached borderline statistical significance are summarized in Table Ib.

\section{DISCUSSION}

In our series of 47 duodenal ulcer subjects with intact stomachs only 20 had a response to insulin judged positive by the criteria of Hollander in the first 45 minutes after the insulin; 20 were positive within one hour; and in five the response was noted in the second hour.

Of considerable interest also is the finding in two patients of a negative response despite the presumed presence of intact vagal pathways. While unusually high basal secretion may help to explain failure to satisfy Hollander's criteria in one patient, no such abnormality was present in the other. Among the possible explanations for these apparently negative responses is that inadequate collections of gastric secretion were made for technical reasons. Duplicate insulin tests were not obtained on these patients, but would probably be required to answer this question. On the other hand, if a small proportion of duodenal ulcer subjects fail to respond 
to insulin it would be important to know whether this finding is restricted to peptic ulcer patients, or is also found in normal subjects and those with other diseases. If such negative responses may be obtained from intact stomachs, this would certainly lessen the confidence of interpretation of such responses after vagotomy operations.

Assuming the vagal nerves of those with the apparently negative responses to insulin to be functionally intact, what differences in behaviour after insulin might they display? First, the hypoglycaemic pattern might have varied. Although detailed studies of the blood sugar curves were not made in these two patients, there was no apparent difference in the values of the fasting and two postinsulin specimens. Second, it is possible that the well known inhibition of gastric acid secretion which tends to occur in the first few minutes after insulin has been much more prolonged in these subjects.

While it may be reasonable to expect that those responding in the second hour after insulin or even those apparently failing to respond to insulin might be explained by a diminished total secretory capacity of the stomach, this was not borne out by parallel lack of response to direct humoral stimulation by a maximal dose of pentagastrin.

Ross and Kay (1964) suggested that a positive acid response in the first 45 minutes after insulin indicated an inadequate and incomplete vagotomy, but that a late response becoming positive between 45 and 120 minutes after insulin might indicate a degree of vagal division which, though to some extent incomplete, was sufficient to give protection against recurrent ulcer. There was a greater reduction in the capacity of the stomach to secrete acid, as judged by maximal histamine response, in those with the late pattern of insulin response, than in those with the early response. Similar findings have been reported by Johnston, Thomas, Checketts, and Duthie (1967). However, these authors found better correlation between the incidence of recurrent ulcer and the timing of the insulin response if an 'early response' included all patients satisfying Hollander's criteria within the first hour after insulin. Despite this further slight modification, however, a considerable incidence of recurrent ulcer was found among patients exhibiting the 'late response' in this series. The closely similar pattern of hypoglycaemic curve in response to insulin in early and late responders in this series fails to reveal any obvious differences in the blood sugar response to insulin which might explain differing behaviour of the acid secretory response in these two groups. It seems clear that, in particular, the rate of fall of blood sugar after a standard dose of insulin does not explain the differences in timing of the positive response. This finding agrees with the work of Demand, Gross, and Berg (1968).

While caution is necessary in comparing responses of the intact stomach to those in the postvagotomized stomach, the occurrence of the 'late positive' and negative patterns of response to insulin in the intact stomach make the interpretation of these types of response after surgical vagotomy still more difficult, and theoretically compatible with intact vagi.

\section{REFERENCES}

Bank, S., Marks, I. N., and Louw, J. H. (1967). Histamine- and insulin-stimulated gastric acid secretion after selective and truncal vagotomy. Gut, 8, 36-41.

Burge, H. W. (1960). Vagotomy in the treatment of peptic ulceration. Postgrad. med. J., 36, 2-12.

Butterfield, W.J.H.(1967). In Third Symposium on Advanced Medicine, edited by A. M. Dawson. Pitman. London.

Davies, J. A. L. (1956). Lateresults of vagotomy combined with gastrojejunostomy or pyloroplasty in the treatment of duodenal ulceration. Brit. med. J., 2, 1086-1091.

Demand, H. A., Gross, H. U., and Berg, G. (1968). Effects of continuous insulin infusions on unstimulated human gastric secretion. Part I. Interrelations between insulin dosage, blood sugar, and gastric secretory changes. Part II. Quantitative changes of the gastric juice pattern. Gastroenterology, 54, 1038-1049.

Feggeter, G. Y., and Pringle, R. (1963). The long term results of bilateral vagotomy and gastrojejunostomy for chronic duodenal ulcer. Surg. Gynec. Obstet., 116, 175-179.

Hollander, F. (1946). The insulin test for the presence of intact nerve fibres after vagal operations for peptic ulcer. Gastroenterology, 7, 607-614.

Holt, R. L., and Lythgoe, J. P. (1961). Ten-year results of vagotomy and gastrojejunostomy in the treatment of chronic duodenal ulcer. Brit. J. Surg., 49, 255-260.

Johnston, D., Thomas, D. G., Checketts, R. G., and Duthie, H. L. (1967). An assessment of postoperative testing for completeness of vagotomy. Ibid, 54, 831-833.

Lythgoe, J. P. (1961). Comparison of the insulin and electrical stimulation tests for completeness of vagotomy. Brit. med. J., 1, 1196-1200.

Ross, B. (1964). Human gastric secretion in response to insulin before and after surgical vagotomy. MD Thesis, University of Sheffield.

_- , and Kay, A. W. (1964). The insulin test after vagotomy. Gastroenterology, 46, 379-386.

Weinstein, V. A., Hollander, F., Lauber, F. U., and Colp, R. (1950). Correlation of insulin test studies and clinical results in a series of peptic ulcer cases treated by vagotomy. Ibid, 14, 214-227.

Woodward, E. R., Harper, P. V., Jr, Tovee, E. B., and Dragstedt, L. R. (1949). Effect of vagotomy on gastric secretion in man and experimental animals. Arch. Surg., 59, 1191-1212. 